\title{
Blockage of driftwood and resulting head increase upstream of an ogee spillway with piers
}

\author{
P. Furlan \\ Laboratory of Hydraulic Constructions ( $\mathrm{LCH}$ ), École Polytechnique Fédérale de Lausanne, Lausanne, \\ Switzerland \\ CERIS, Instituto Superior Técnico, Universidade de Lisboa, Lisbon, Portugal
}

M. Pfister

Haute école d'ingénierie et d'architecture Fribourg (HEIA), HES-SO, Switzerland

J. Matos

CERIS, Instituto Superior Técnico, Universidade de Lisboa, Lisbon, Portugal.

\author{
A.J. Schleiss \\ Laboratory of Hydraulic Constructions ( LCH), École Polytechnique Fédérale de Lausanne, Lausanne, \\ Switzerland
}

\begin{abstract}
Accumulations of floating debris in reservoirs can have negative impacts on the safe operation of a dam. Thus, adequate spillway design in view of driftwood is of paramount importance. Herein, investigation of driftwood blockage with a reservoir flow approach was conducted. A laboratory facility was used to evaluate blockage of artificial stems at an ogee crested spillway equipped with piers. With a systematic approach, the effect of blocked stems on the head at a reservoir was qualitatively investigated. Experiments with manually blocked stems were performed to study the effect a blockage can have on the reservoir head. Experiments releasing 200 stems were performed to study jam shapes and their probability to cause a head increase. It was found that similar blocked volumes of stems had different effects on the head increase in the reservoir and were dependent on whether stems were in contact or not with the spillway crest. It was also found that an increasing head tends to decrease the blocking probability but not linearly.
\end{abstract}

RÉSUMÉ: L'accumulation de bois flottants dans les réservoirs peut avoir des effets négatifs sur la sécurité de l'exploitation d'un barrage. Par conséquence, une conception adéquate des déversoirs en ce qui concerne le bois flottant est d'une importance primordiale. Ici, une étude sur le blocage du bois flottant avec une approche d'écoulement de réservoir a été menée. Un modèle physique a été utilisé pour évaluer le blocage des tiges artificielles sur un déversoir à crête standard équipé avec des piliers. Grace a une approche systématique, l'effet des tiges bloquées sur la tête d'un réservoir a été étudié qualitativement. Des expériences avec des tiges bloquées manuellement ont été réalisées pour étudier quel effet, qu'un blocage, peut avoir sur la tête du réservoir. Des expériences en libérant 200 tiges ont été réalisées pour étudier les formes d'encombrement et leur probabilité de provoquer une augmentation de la tête. Il a été constaté que des volumes de tiges bloqués similaires avaient des effets différents sur l'augmentation de la tête dans le réservoir et dépendaient du fait que les tiges étaient en contact ou non avec la crête de l'évacuateur de crue. Il a également été constaté qu'une tête croissante tend à diminuer la probabilité de blocage, mais pas de manière linéaire. 


\section{INTRODUCTION}

In forested water courses, entrapment and transportation of driftwood is a natural process. Floods can initiate the transport of such floating material when passing through forested areas. When the floating material is composed by stems typically longer than $1 \mathrm{~m}$ and larger than $0.10 \mathrm{~m}$ in diameter, it is called large wood (LW) (Braudrick, Grant, Ishikawa, \& Ikeda, 1997; Ruiz-Villanueva, Piégay, Gurnell, Marston, \& Stoffel, 2016; Wohl et al., 2016). However, blockage of LW in hydraulic constructions like weirs, bridges or spillways can significantly undermine the behavior of the structure to varying extents (see examples of LW jams at spillways in Figure 1). Depending on the characteristics of the LW jam and the blocked structure, some hazardous situations can develop as for example, increased upstream flooded area, unforeseen loads, or decreased flood discharge capacity.

A hydraulic structure may start to become blocked at low water levels and fully develop a LW jam at peak discharge (Spreitzer, Friedrich, \& Tunnicliffe, 2018). For this reason, it is important to understand under which hydraulic conditions blockage has higher probabilities of occurrence. Additionally, the characteristics of the woody material also influence the blocking probability. It has been noted that wood density has an important role when determining the threshold of movement for stems in a riverine environment (Braudrick \& Grant, 2000). Regarding the blocking process of driftwood at hydraulic structures, wood density has proven to be an influential parameter when the stem length is greater than the bay width of a spillway with a reservoir flow approach. Under those conditions, an increasing wood density can increase the blocking probability of an ogee crested spillway equipped with piers (Furlan, Pfister, Matos, \& Schleiss, 2018). In view of the stem length, is generally recommended to design bays, or spacing between piers, of at least 0.80 times the relevant tree height in a certain catchment for assuring a low blocking probability $(<0.20)$ (CFBR, 2013; Swiss Committee on Dams, 2017).

The objective of the present contribution is to quantify the resulting head increase due to a constricted cross-section, in this case, an ogee crested spillway equipped with piers. In previous papers, quantifications of the influence of wood density, stem length and diameter for blocking probabilities estimations have been done (Furlan, 2018; Furlan, Pfister, Matos, \& Schleiss, 2017, 2018). These, have been related to the hydraulic conditions and structure's characteristics throughout the width of the spillway bay and the head at the weir crest. Thus, herein the goal is to understand and quantify the resulting head increase in a reservoir due to a $\mathrm{LW}$ blockage using systematic laboratory experiments.
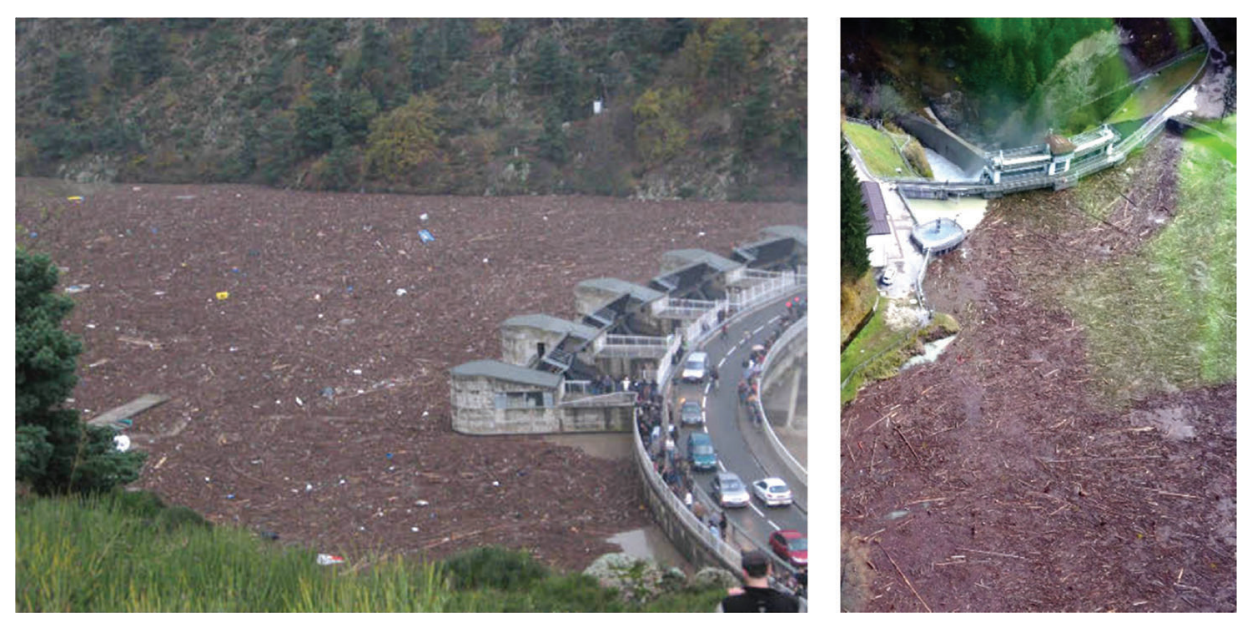

Figure 1. LW jams at a spillway in Loire, France on November 2008 (innondationloire.canalblog.com) (left). LW jams at a spillway in Belluno, Italy in October 2018 (corrieredelveneto.corriere.it) (right). 


\section{PHYSICAL MODEL}

\subsection{Laboratory facility}

A laboratory facility was constructed in the Laboratory of Hydraulic Constructions (LCH) of Ecole Polytechnique Fédérale de Lausanne (EPFL), Switzerland. The model was composed by an ogee crested spillway with five symmetrical bays $(b=0.26 \mathrm{~m})$ constructed with PVC, following the WES design criteria (design head $\mathrm{H}_{\mathrm{d}}=0.15 \mathrm{~m}$ ) (U. S. Army Corps of Engineers, 1987). The ogee was chosen due to its broad application and study. The piers were round-nose piers and protruded $0.04 \mathrm{~m}$ upstream of the vertical face of the spillway into the reservoir (Figure 2). The channel had a length of $10 \mathrm{~m}$, with a rectangular cross-section of $1.50 \mathrm{~m}$ wide and $0.70 \mathrm{~m}$ high.

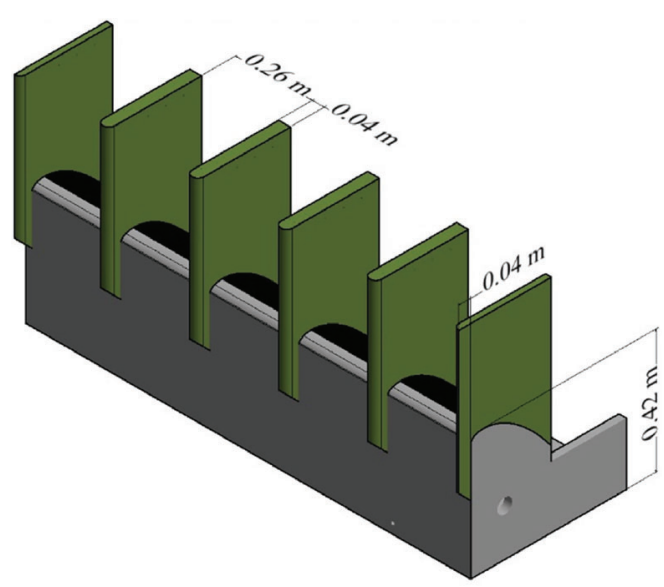

Figure 2. Schematic representation of the ogee crested spillway with the round-nose piers.

The reservoir level $h(\mathrm{~m})$ was measured using an ultrasonic distance sensor $( \pm 0.3 \mathrm{~mm})$ at $2.60 \mathrm{~m}$ upstream of the model. The discharge $Q\left(\mathrm{~m}^{3} / \mathrm{s}\right)$ was measured with a magnetic inductive flow meter $( \pm 0.5 \%$ at full span). Small magnitudes of reservoir flow velocity were used to represent a reservoir flow approach.

A mechanical equipment was designed to supply stems into the channel. It consisted of a horizontal plate of PVC of 1.00 per $0.50 \mathrm{~m}$. The plate could be manually tilted to gently release the stems. Two columns allowed to regulate the height of the plate according to the flow depth so the stems would not plunge into the flume when released.

\subsection{Artificial stems}

In order to represent LW systematically, artificial plastic stems were defined with a simplified cylindrical geometry. The size of the artificial stems in the experiments reproduces the sizes of trees blocked at different hydraulic structures in Switzerland after a flood in 2005 (Bezzola \& Hegg, 2007). Four categories of wood density were represented, covering a range from light wood $(0.40-0.47 \mathrm{t} / \mathrm{m} 3$ (Chave et al., 2009)) up to waterlogged logs that have a wood density close to the water density (Buxton, 2010). The stem density was normalized with the water density, providing a dimensionless parameter, the relative steam density $\left(\rho_{s}\right)$. Stems were separated in different classes according to their size (Table 1). 
Table 1. Characteristic of the artificial stems used in the laboratory facility.

\begin{tabular}{lllll}
\hline Class & Length $L[\mathrm{~m}]$ & Diameter $d[\mathrm{~m}]$ & Length/Bay width $L / b[-]$ & Relative density $\rho_{S}[-]$ \\
\hline A & 0.21 & 0.01 & 0.80 & 0.59 \\
& & & & 0.79 \\
B & 0.26 & 0.012 & 1.00 & 0.99 \\
C & 0.30 & 0.016 & 1.20 & 0.56 \\
& & & & 0.43 \\
& & & 1.50 & 0.56 \\
D & 0.40 & 0.02 & 2.00 & 0.97 \\
E & 0.52 & & & 0.63 \\
& & & & 0.40 \\
& & & & 0.54 \\
& & &
\end{tabular}

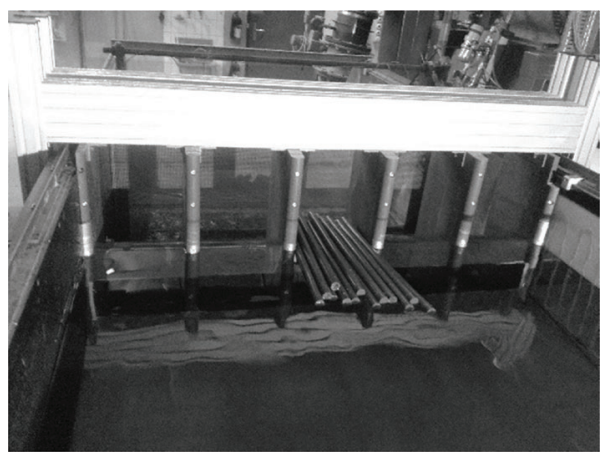

Figure 3. Example of the stems artificially blocked. Group of 16 stems. Courtesy of Selene Hewes.

\subsection{Experimental methodology}

To quantify the resulting change of a reservoir level due to blocked stems, a systematic set of experiments was conducted. The reservoir level was measured without stems as initial condition. Consecutively, groups of stems were manually blocked at the central bay of the spillway (Figure 3).

The new reservoir level was measured after 5 minutes, three times. Stems were manually positioned parallel to the flow direction as it was observed to be a critical situation in other experiments of this project. The experimental program to systematically measure the head

Table 2. Experimental program for evaluating systematically head increase.

\begin{tabular}{llll}
\hline Exp. N & Class & $H / d[-]$ & Group size $G_{i}[-]$ \\
\hline 1 & $\mathrm{~A}$ & 1.00 & $4 ; 8 ; 16 ; 32$ \\
2 & & 1.20 & $4 ; 8 ; 16 ; 32$ \\
3 & $\mathrm{C}$ & 0.94 & $4 ; 8 ; 16 ; 32$ \\
4 & & 1.00 & $4 ; 8 ; 16 ; 32$ \\
5 & & 1.06 & $4 ; 8 ; 16 ; 32$ \\
6 & $\mathrm{E}$ & 0.76 & $8 ; 16 ; 32$ \\
7 & & 0.84 & $4 ; 8 ; 16 ; 32$ \\
8 & & 0.96 & $4 ; 8 ; 16 ; 32$ \\
\hline
\end{tabular}


increase in the reservoir included experiments with different stem classes and heads (Table 2). The stems tested represented the average wood density of dry trees in Europe $(0.47-0.67 \mathrm{t} /$ $\mathrm{m}^{3}$ ) (Chave et al., 2009).

In the systematic experiments (Table 2 ) the ratios of head $H$ to stem diameter $d(H / d$, relative head) ranged from 0.76 to 1.20 . The heads used in the experiments varied from 0.010 to $0.024 \mathrm{~m}$. Since they may be affected by scale effects, they are considered as qualitative results.

To quantify how large numbers of stems block and lead to head increases at an ogee crested spillway, with a reservoir flow approach, other experiments were performed. For this, a batch of 200 stems was used. The batch was supplied aligned with the central bay using a mechanical equipment (Figure 4).

The distribution of sizes and densities of stems inside the batch is based on the findings in Switzerland after a flood in 2005 (Table 3) (Bezzola \& Hegg, 2007).

First, the reservoir level was measured without stems as the initial condition. Then, stems were supplied to the flume and it was noted how many blocked. A new measurement of the reservoir level was taken after 10 minutes. Notes and pictures were taken during the experiments. Two heads were evaluated in these experiments (Table 4). For estimating the blocking probability, 30 and 25 independent repetitions were performed to assure statistical accuracy of the results (Furlan, Pfister, Matos, Amado, \& Schleiss, 2018). With it, a blocking probability $\hat{\Pi}$ was estimated as the ratio of blocked stems divided by the number of supplied stems and averaged in the repetitions.

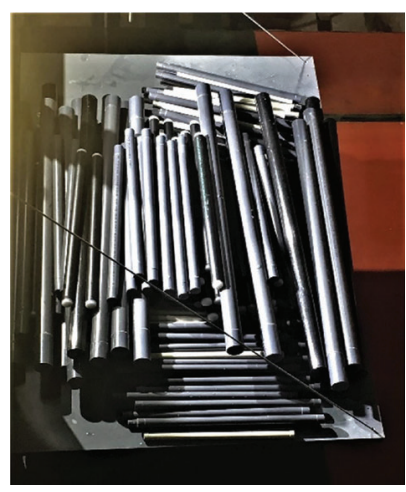

Figure 4. Stem batch arranged to be supplied with the mechanical equipment.

Table 3. Batch composition with artificial stems.

\begin{tabular}{lllll}
\hline Class & $\begin{array}{l}\text { Relative stem density [-] } \\
{[0.40-0.47]}\end{array}$ & {$[0.48-0.67]$} & {$[0.68-0.88]$} & {$[0.89-0.99]$} \\
\hline A & & 30 & 40 & 15 \\
B & & 39 & & \\
C & 20 & 20 & & \\
D & & 18 & 6 & 6 \\
E & & 6 & & \\
\hline
\end{tabular}

Table 4. Experimental program for evaluating blockage of a batch and resulting head increase.

\begin{tabular}{llll}
\hline Exp. $\mathrm{N}^{\circ}$ & Stems [-] & $H[\mathrm{~m}]$ & Repetitions [-] \\
\hline 9 & 200 & 0.028 & 30 \\
10 & & 0.030 & 25 \\
\hline
\end{tabular}




\section{RESULTS}

\subsection{Systematic measurements of head increase for manually blocked stems}

According with the results obtained for the manually blocked stems (Table 2), the reservoir level tends to increase with increasing number of manually blocked stems (Table 5). For the same stem class and group size, a higher head leads to a higher reservoir level increase in most of the experiments performed.

Table 5. Experimental measurements of head increase $(\Delta \mathrm{H})$ due to different stem group sizes (Gi) manually blocked [mm].

\begin{tabular}{|c|c|c|c|c|}
\hline & & $\Delta \mathrm{H}$ & $\Delta \mathrm{H}$ & \\
\hline \multirow{5}{*}{ A } & $\mathrm{G}_{\mathrm{i}}$ & Exp. $1(\mathrm{H} / \mathrm{d}=1.00)$ & Exp. $2(\mathrm{H} / \mathrm{d}=1.20)$ & \\
\hline & 4 & 0.03 & 0.03 & \\
\hline & 8 & 0.02 & 0.04 & \\
\hline & 16 & 0.05 & 0.09 & \\
\hline & 32 & 0.14 & 0.12 & \\
\hline \multirow{5}{*}{$\mathrm{C}$} & & $\Delta \mathrm{H}$ & $\Delta \mathrm{H}$ & $\Delta \mathrm{H}$ \\
\hline & $\mathrm{G}_{\mathrm{i}}$ & Exp. $3(\mathrm{H} / \mathrm{d}=0.94)$ & Exp. $4(\mathrm{H} / \mathrm{d}=1.00)$ & Exp. $5(\mathrm{H} / \mathrm{d}=1.06)$ \\
\hline & 4 & 0.00 & 0.02 & 0.06 \\
\hline & 8 & 0.07 & 0.04 & 0.12 \\
\hline & 16 & 0.20 & 0.13 & 0.16 \\
\hline \multirow{7}{*}{$\mathrm{E}$} & 32 & 0.17 & - & 0.18 \\
\hline & & $\Delta \mathrm{H}$ & $\Delta \mathrm{H}$ & $\Delta \mathrm{H}$ \\
\hline & $\mathrm{G}_{\mathrm{i}}$ & Exp. $6(\mathrm{H} / \mathrm{d}=0.76)$ & Exp. $7(\mathrm{H} / \mathrm{d}=0.84)$ & Exp. $8(\mathrm{H} / \mathrm{d}=0.96)$ \\
\hline & 4 & - & 0.00 & 0.10 \\
\hline & 8 & 0.15 & 0.20 & 0.16 \\
\hline & 16 & 0.20 & 0.25 & 0.34 \\
\hline & 32 & 0.17 & 0.20 & 0.29 \\
\hline
\end{tabular}

When normalizing the increase of the reservoir level with the initial head, this trend becomes clearer (Figure 5). The maximum normalized head increase measured is almost 0.15 when blocking one bay, out of five, with 16 stems of class $\mathrm{E}(d=0.025 \mathrm{~m})$.

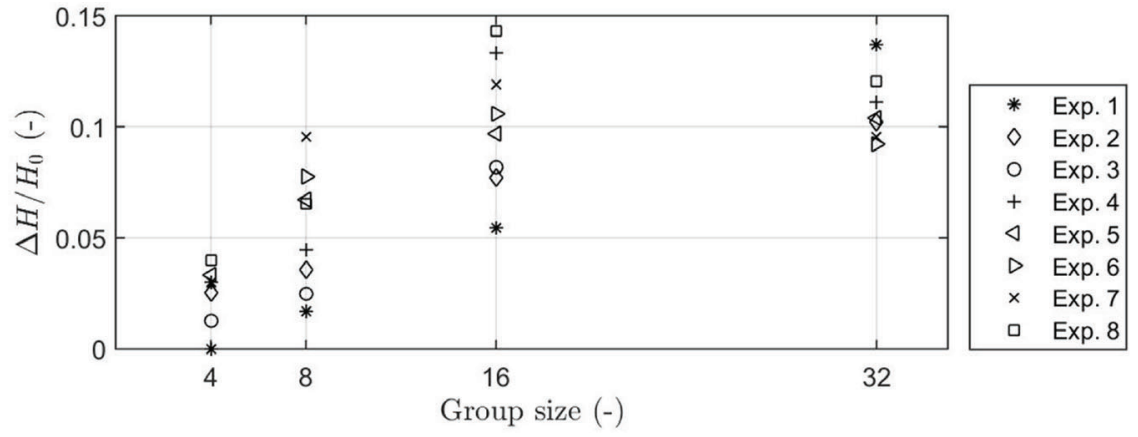

Figure 5. Normalized head increase $\left(\Delta \mathrm{H} / \mathrm{H}_{0}\right)$ as a function of group size artificially blocked, experiments from Table 2. 


\subsection{Measurements of head increase for 200 stems mechanically supplied}

The blocking probability $\hat{\Pi}$ for the batch was estimated as the number of stems blocked divided by the number of stems supplied (200). Under the tested conditions, a batch of 200 heterogeneous artificial stems with $H_{0}=0.028 \mathrm{~m}$ has low blocking probability $\hat{\Pi}=0.20$ (averaging 30 repetitions; standard deviation of 0.09 ). For $H_{0}=0.030 \mathrm{~m}, \hat{\Pi}=0.16$ (averaging 25 repetitions; standard deviation of 0.08 ). Therefore, less than 40 stems of the batch are more likely to block than higher numbers of stems at the spillway inlet for these scenarios.

A ratio between the volume blocked and the volume supplied of stems has been linked to the head increase occurrence in Figure 6 for $H_{0}=0.028 \mathrm{~m}$ and in Figure 7 for $H_{0}=0.030 \mathrm{~m}$. For ratios of blocked stems to supplied stems smaller than 0.20 , there was not an increase in the reservoir level. Once the blocked volume starts to increase, the normalized head increases to values higher than zero.

As the pier nose was separating the carpet of stems upstream of the ogee crested weir, the frequency of not having a head increase was higher than 0.60 (Figure 8). However, for some cases of blockage a head increase was measured with a lower frequency.

Due to the supply method of the batch (Figure 4), stems were able to move above each other in several vertical layers. These multilayer groups of stems were observed to influence the blockage process. The different combinations and interactions amidst stems gave various geometries of jams and thus different characteristics of the blockage

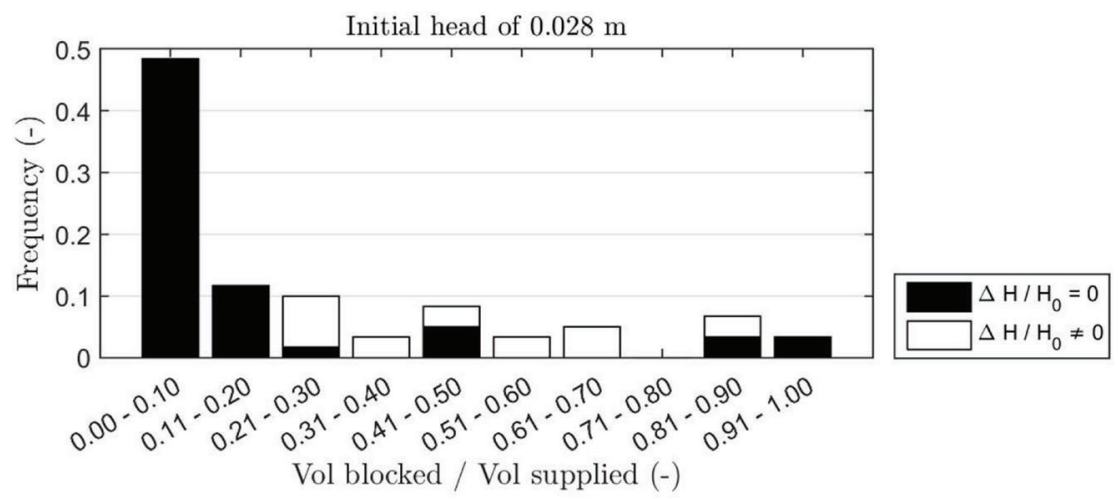

Figure 6. Frequency of occurrence of the normalized head increase $\left(\Delta \mathrm{H} / \mathrm{H}_{0}\right)$ at the reservoir as a function of the ratio of blocked volume and supplied volume for an initial head of $0.028 \mathrm{~m}$.

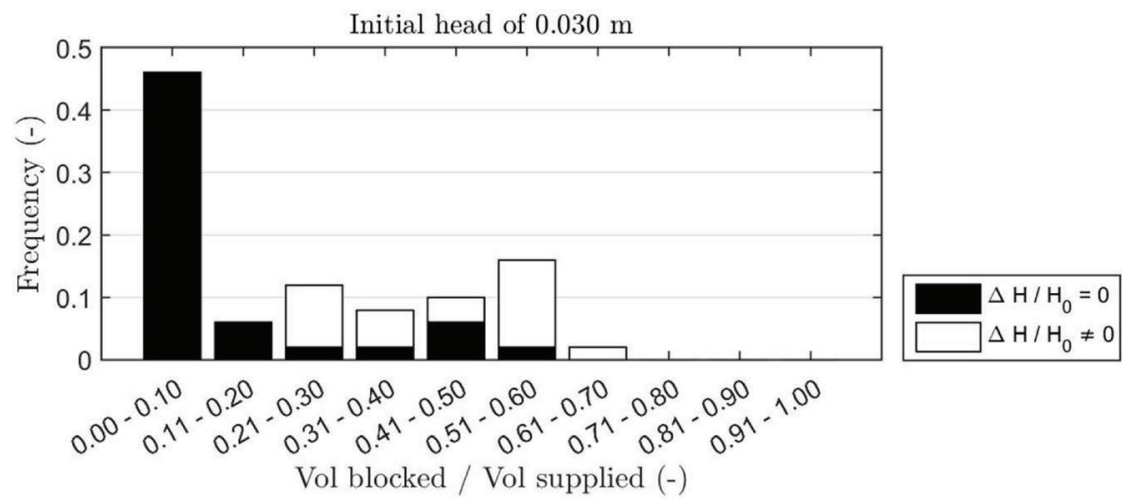

Figure 7. Frequency of occurrence of the normalized head increase $\left(\Delta \mathrm{H} / \mathrm{H}_{0}\right)$ at the reservoir as a function of the ratio of blocked volume and supplied volume for an initial head of $0.030 \mathrm{~m}$. 


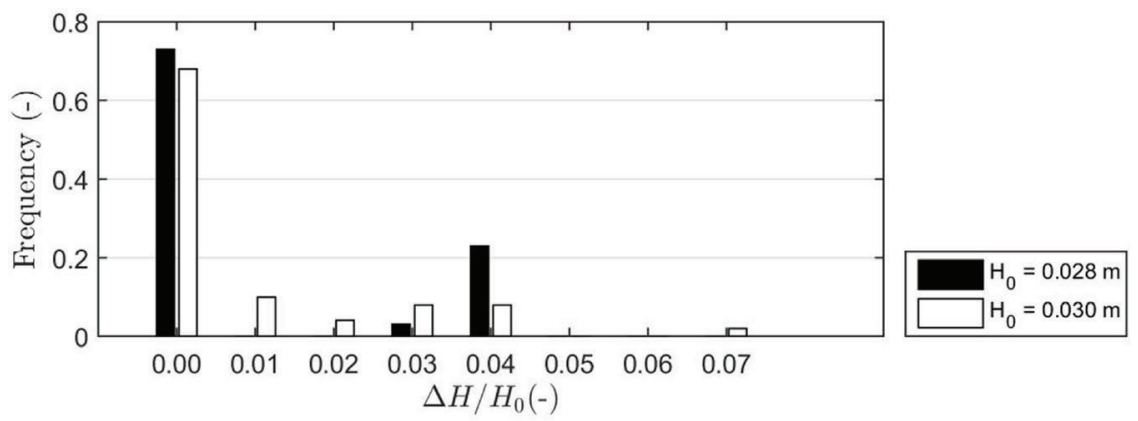

Figure 8. Frequency of normalized head increase measurements $\left(\Delta \mathrm{H} / \mathrm{H}_{0}\right)$ for a batch of 200 artificial stems with a reservoir flow approach.

(a)

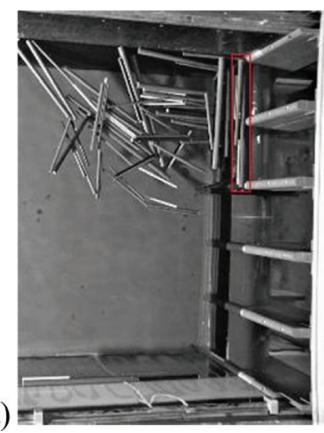

(b)

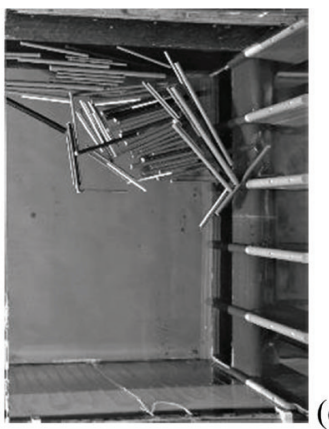

(c)

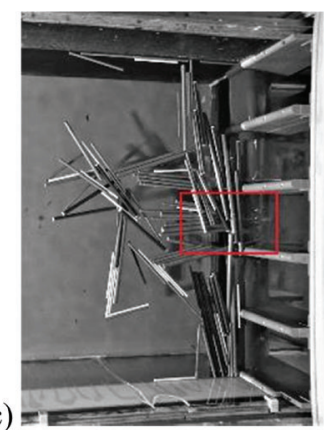

Figure 9. Recognized scenarios of blockage. (a) Stems bridging between piers and a floating carpet upstream, no reservoir level increase. (b) Stems oblique to the flow direction, random possibility of reservoir level increase. (c) Stems parallel to the flow direction, stronger possibility of reservoir level increase.

In the experiments, the shape and composition of jams was random, and it changed from one experimental repetition to the next. An equal blocked volume of stems could sometimes induce an increase in the reservoir level and others not. Therefore, the position of the jam respect to the weir crest and the pier nose was visually evaluated.

Generally, if stems would block perpendicular to the flow direction (bridging between two piers) a floating carpet of stems would develop (Figure 9a). In this situation, the LW jam would not reach the weir crest and no increase in the reservoir level was measured. On the other hand, if stems would block parallel to the flow direction (occupying one complete bay or more) a condensed LW jam would develop (Figure 9c). In those cases, an increase of the reservoir level was measured. There was an intermediate case where stems would block oblique to the flow direction. In those scenarios the resulting increase was random, leading to a head increase only in some cases (Figure 9b).

\section{DISCUSSION}

The experiments revealed, as expected, that a head increase in the reservoir is highly linked to the blocked volume of large wood, the jam shape and composition. This increase in the reservoir level is linked to a decreased discharge capacity or, in other terms, a modified free flow area. The relation of different blocked areas with stems and the resulting head increase is still being analysed from the systematic experiments (Table 2). In parallel, a theoretical 
formulation to estimate the normalized head increase at a reservoir, as a function of the occupied space by stems, is ongoing.

From the experiments performed, it could be observed that the location of the spillway may influence the blockage. The movement of stems for a reservoir flow approach is erratic but stems tend to align to the flow direction close to the weir. If the space for stems to turn freely is not available, blockage may be increased. When a small number of stems is approaching a spillway, it may be preferable to open all the bays as generally it can decrease the blocking probability compared to a single open bay (for constant hydraulic conditions) (Furlan, 2018).

According to the experimental observations, the firsts stems that block at the weir tends to determine the shape and composition of the jam, thus becoming key elements that control the blockage process. To relate the possibility of head increase with blocked volumes of stems, it is necessary to include the geometrical characteristics of the jam, distance to the crest and orientation together with stem jam composition.

Only one geometry of pier nose was evaluated. With a nose protruding into the vertical face of the spillway, the floating carpet of stems was kept away of the weir crest. If the protrusion of the pier nose is decreased, it is possible that a carpet of floating stems upstream of the weir crest affects the head. Therefore, increasing the pier nose protrusion may be considered as a safety measure against large wood blockage at weirs equipped with piers. This analysis is valid for a reservoir flow approach only where the carpet of stems is not compressed against the piers. If flow velocities are increased, in river flow scenarios comparable to those of Schalko, Schmocker, Weitbrecht, \& Boes, (2018) or Schmocker \& Hager, (2013), it is possible that the LW jam affects the discharge capacity of the spillway due to the condensed volume of stems stacking upstream of the piers.

\section{CONCLUSIONS}

As a preventive measure to limit the head increase at a reservoir spillway, piers which are protruding into the reservoir are recommended. When a floating carpet of stems is blocked upstream of the piers without touching the weir crest, generally, it does not affect the discharge capacity of the weir and does not result in a head increase. Therefore, a protruding pier nose may keep the free flow capacity of an ogee crested weir. However, for a case of one complete bay occupied by stems, the experiments resulted in a maximum normalized head increase $\left(\Delta \mathrm{H} / \mathrm{H}_{0}\right)$ of approximately $15 \%$. Further research is being completed to develop a theoretical formulation that helps estimating the head increase at a reservoir with a blocked ogee crested spillway equipped with piers.

\section{ACKNOWLEDGEMENTS}

This project is supported by "Fundação para a Ciência e a Tecnologia" (FCT) from Portugal (PD/BD/52664/2014) under IST - EPFL joint PhD initiative H2Doc. Further support was provided by the Laboratory of Hydraulic Constructions (LCH, EPFL), Switzerland, and Électricité de France (EDF), France under contract No. 5500-5920006472. The authors would like to thank the assistance of Selene Hewes for her contribution during the experimental campaign at EPFL.

\section{REFERENCES}

Bezzola, G. R., \& Hegg, C. (2007). Ereignisanalyse Hochwasser 2005, Teil 1 - Prozesse, Schäden und erste Einordnung. (G. R. Bezzola \& C. Hegg, Eds.) (Vol. 0707). Bern. https://doi.org/Umwelt-Wissen Nr. 0707

Braudrick, C. A., \& Grant, G. E. (2000). When do logs move in rivers? Water Resources Research, 36 (2),571-583. https://doi.org/10.1029/1999WR900290 
Braudrick, C. A., Grant, G. E., Ishikawa, Y., \& Ikeda, H. (1997). Dynamics of Wood Transport in Streams: A Flume Experiment. Earth Surface Processes and Landforms, 22(7),669-683. https://doi. org/10.1002/(SICI)1096-9837(199707)22:7<669::AID-ESP740>3.0.CO;2-L

Buxton, T. H. (2010). Modeling entrainment of waterlogged large wood in stream channels. Water Resources Research, 46(July), 1-15. https://doi.org/10.1029/2009WR008041

CFBR. (2013). Guidelines for dam spillway design. http://www.barrages-cfbr.eu/IMG/pdf/recommanda tions_cfbr_2013_evc.pdf

Chave, J., Coomes, D., Jansen, S., Lewis, S. L., Swenson, N. G., \& Zanne, A. E. (2009). Towards a worldwide wood economics spectrum. Ecology Letters, 12(4),351-366. https://doi.org/10.1111/j.14610248.2009.01285.x

Furlan, P. (2018). Blocking probability of large wood and resulting head increase at ogee crest spillways. Doctoral thesis. École Polytechnique Fédérale de Lausanne, Switzerland. Instituto Superior Técnico, Universidade de Lisboa, Portugal.

Furlan, P., Pfister, M., Matos, J., Amado, C., \& Schleiss, A. J. (2018). Experimental repetitions and blockage of large stems at ogee crested spillways with piers. Journal of Hydraulic Research, 1686, 113. https://doi.org/10.1080/00221686.2018.1478897

Furlan, P., Pfister, M., Matos, J., \& Schleiss, A. J. (2017). Entrainement de bois flottant dans un déversoir a crête standard avec piliers: Influence des caractéristiques de bois flottant en probabilités de blocage. In Colloque CFBR-SHF, Hydraulique des barrages et des digues, 29-30 novembre 2017, Chambéry, France. (pp. 42-49). Société hydrotechnique de France. https://doi.org/10.24346/ cfbr_shf_colloque2017_a04

Furlan, P., Pfister, M., Matos, J., \& Schleiss, A. J. (2018). Influence of density of large stems on the blocking probability at spillways. In 7th IAHR International Symposium on Hydraulic Structures, Aachen, Germany, 15-18 May (pp. 1-8). https://doi.org/10.15142/T3664S(978-0-692-13277-7)

Ruiz-Villanueva, V., Piégay, H., Gurnell, A. M., Marston, R. A., \& Stoffel, M. (2016). Recent advances quantifying the large wood dynamics in river basins: New methods and remaining challenges. Reviews of Geophysics, 54(3),611-652. https://doi.org/10.1002/2015RG000514

Schalko, I., Schmocker, L., Weitbrecht, V., \& Boes, R. M. (2018). Backwater Rise due to Large Wood Accumulations. Journal of Hydraulic Engineering, 144(9), 04018056. https://doi.org/10.1061/(ASCE) HY.1943-7900.0001501

Schmocker, L., \& Hager, W. H. (2013). Scale Modeling of Wooden Debris Accumulation at a Debris Rack. Journal of Hydraulic Engineering, 139(8),827-836. https://doi.org/10.1061/(ASCE)HY.19437900.0000714

Spreitzer, G., Friedrich, H., \& Tunnicliffe, J. (2018). Effects of a large woody debris accumulation on channel-bed morphology during flood events. E3S Web of Conferences, 40, 02024. https://doi.org/ $10.1051 / \mathrm{e} 3$ sconf $/ 20184002024$

Swiss Committee on Dams. (2017). Floating debris at reservoir dam spillways. http://www.swissdams.ch/ en/publications/publications-csb/2017_Floating\%20debris.pdf

U. S. Army Corps of Engineers. (1987). Hydraulic design of spillways. Engineer Manual 1110-2-1603.

Wohl, E., Bledsoe, B. P., Fausch, K. D., Kramer, N., Bestgen, K. R., \& Gooseff, M. N. (2016). Management of Large Wood in Streams: An Overview and Proposed Framework for Hazard Evaluation. JAWRA Journal of the American Water Resources Association, 52(2),315-335. https://doi.org/ $10.1111 / 1752-1688.12388$ 